\title{
Alpha-hydroxybutyrate dehydrogenase activity in sex-linked muscular dystrophy
}

\author{
H. A. JOHNSTON, ${ }^{1}$ J. H. WILKINSON, ${ }^{2}$ WENDY A. WITHYCOMBE, ${ }^{3}$ \\ AND S. RAYMOND ${ }^{2}$
}

\begin{abstract}
From the Medical Research Council Population Genetics Research Unit, Oxford, the Department of Chemical Pathology, Westminster Medical School, University of London, and the Pepper Laboratory of Clinical Medicine, University of Pennsylvania, Philadelphia, Pa., U.S.A.
\end{abstract}

SYNOPSIS In two families with severe sex-linked muscular dystrophy, high levels of $\alpha$-hydroxibbutyrate dehydrogenase (HBD), lactate dehydrogenase (LD), aspartate transaminase (Asp B), aldolase, and creatine phosphokinase (CPK) were found in the sera of three young affected males. In both families the mother had a raised level of HBD activity. Four sisters of the three affected boys had raised serum enzyme levels, and they are regarded as presumptive carriers of the disea Biopsy specimens of dystrophic muscle had LD and HBD contents which were significantly lower than those of control specimens, while the $\mathrm{HBD} / \mathrm{LD}$ ratios were markedly greater. Muscle from thgo unaffected members of the same family also exhibited high ratios, indicating the presence of the electrophoretically fast LD isoenzymes, and this was confirmed by acrylamide-gel electrophoress.

Measurement of the serum a-hydroxybutyrate dehydrogenase activity has provided a convenient means for the detection of a relative increase in the electrophoretically fast-migrating lactate dehydrogenase isoenzymes, $\mathrm{LD}_{1}$ and $\mathrm{LD}_{2}$ (Rosalki and Wilkinson, 1960; Plummer, Elliott, Cooke, and Wilkinson, 1963), and has proved to be a useful diagnostic test in myocardial infarction and other conditions in which $L D_{1}$ and $L D_{2}$ are released into the circulation (Elliott and Wilkinson, 1961; Konttinen, 1961 ; Pagliaro and Notarbartolo, 1961; Rosalki, 1963). Elevated serum HBD activities have been reported in patients with the clinically severe type of progressive muscular dystrophy (Pagliaro and Notarbartolo, 1961; Elliott and Wilkinson, 1963), and several investigators have reported a relative increase in the proportions of $L D_{1}$ and $L D_{2}$ in biopsy specimens of skeletal muscle taken from patients with this disease (Richterich, Gautier, Egli, Zuppinger, and Rossi, 1961; Wieme and Herpol, 1962; Dreyfus, Démos, Schapira, and Schapira, 1962; Wieme and Lauryssens, 1962).

We recently had the opportunity to study muscle

\footnotetext{
'Present address: Department of Medicine, University of Manchester. ${ }^{2}$ Present address: Pepper Laboratory of Clinical Medicine, University of Pennsylvania, Philadelphia, U.S.A.

${ }^{3}$ Present address: Department of Chemical Pathology, St. Mary's Hospital Medical School, University of London.

Received for publication 12 November 1965.
}

biopsy specimens and sera from a family (family with presumptive evidence of sex-linked inheritance for severe muscular dystrophy, and sera froth another family (family B) with known sex-linked inheritance. The relative and total HBD and IDD activities in muscle extracts were compared with isoenzyme patterns obtained after electrophoresis 8 n cellulose acetate foil and in acrylamide gel. The serum aspartate and alanine transaminase (Asg T and AlT, formerly known as glutamic-oxaloacêtic and glutamic-pyruvic transaminase (SGOT a SGPT), aldolase and creatine phosphokinase (CPK) levels were also determined since abnormal activity of these enzymes in the serum is known to occuryt progressive muscular dystrophy (Sibley and Lehninger, 1949; Schapira, Dreyfus, and Schapinga, 1953; Pearson, 1957; Dreyfus, Schapira, and Schapira, 1958; Thompson and Vignos, 1959; Ebashi, Toyokura, Momoi, and Sugita, 1959; Dreyfus, Schapira, and Démos, 1960; Thomso. Leyburn, and Walton, 1960; Hughes, 1963).

METHODS

CLINICAL In the two families, all available membërs were clinically examined and full details of famply histories were noted. In all the affected boys, include those deceased, the onset of the disease was in infarey with rapid progression to immobility in early adolescenee. 
I

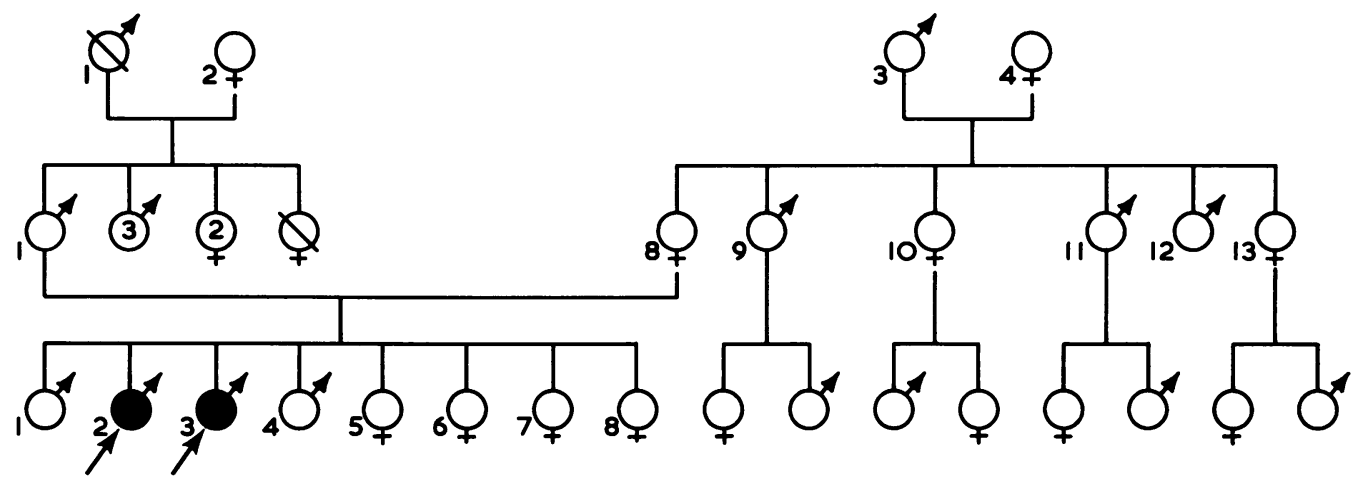

FIG. 1. Family tree of the A family. The black symbols represent individuals with progressive muscular dystrophy and oblique lines denote deceased members of the family.

I

II

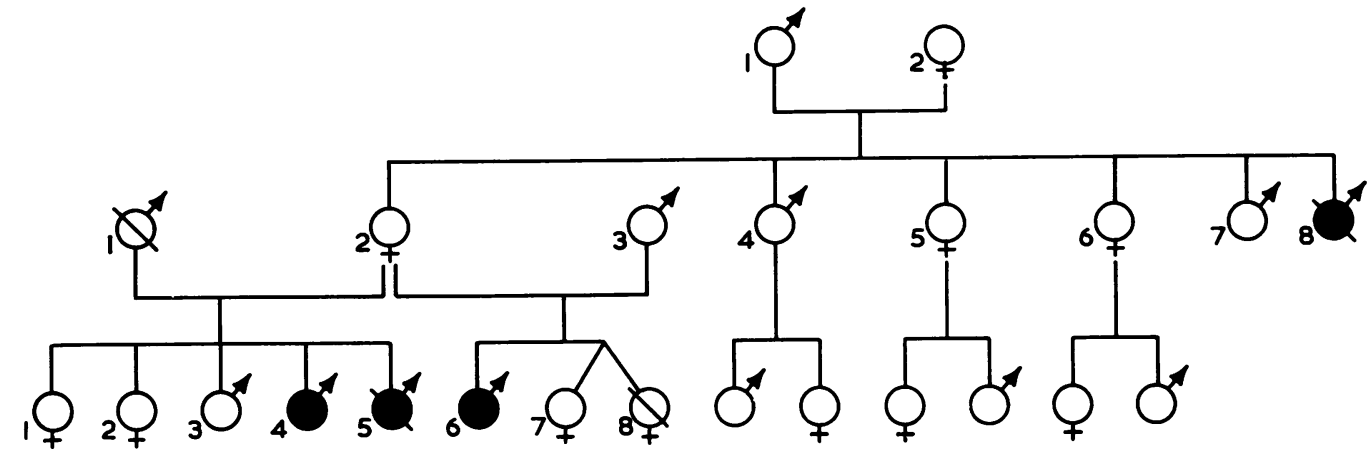

FIG. 2. Family tree of the B family. The symbols have the same significance as those in Figure 1.

All the affected individuals had a history of pseudohypertrophy of the calves with initial onset of the condition in the muscles of the pelvic girdle and spread to those of the shoulder girdle. In family A (Fig. 1) biopsies of the triceps muscle were obtained under local anaesthetic from the two affected sibs, $\mathrm{III}_{2}$ and $\mathrm{III}_{3}$, the unaffected male sib, $\mathrm{III}_{4}$, and the mother, $\mathrm{II}_{8}$. Sera were available from 12 members of this family including the mother's parents. There was no history of the disease in any previous generation.

In family B (Fig. 2) sera were available from only one of the two living affected sibs $\left(\mathrm{III}_{6}\right)$ and from five other members, including the mother's sister $\left(\mathrm{II}_{5}\right)$, who has an unaffected son and daughter.

Some difficulty was experienced in obtaining suitable control muscle, as it has recently been shown that the LD isoenzyme patterns of skeletal muscles differ according to whether they consist of predominantly red or white fibres (Dawson, Goodfriend, and Kaplan, 1964; Brody, 1964; Rosalki, 1964). In red muscle, e.g., soleus, most of the enzyme occurs in the fast fractions $\mathrm{LD}_{1}$ and $\mathrm{LD}_{2}$, whereas in white muscle, e.g., gastrocnemius, the slow fractions are the characteristic forms. Two specimens of triceps muscle, taken at necropsy, were used as controls and these were supplemented by seven biopsy specimens of latissimus dorsi taken from patients undergoing thoracic surgery. In none of these cases was there a history of cardiac, hepatic, haematological, or muscular disease.

Blood was collected by venepuncture into plain glass bottles. The serum, which was separated within an hour, was stored frozen at $-18^{\circ} \mathrm{C}$. during transit and until enzyme activity was determined.

DETERMINATION OF ENZYME ACTIVITY The activities of SLD and SHBD were determined spectrophotometrically at $25^{\circ} \mathrm{C}$. by the methods of Wróblewski and LaDue (1955) and Rosalki and Wilkinson (1960) respectively. Muscle extract, diluted with $0.067 \mathrm{M}$-Sørensen phosphate buffer ( $p \mathrm{H} 7 \cdot 4)(0.1 \mathrm{ml}$.$) , was mixed with phosphate buffer$ $(2.7 \mathrm{ml})$, reduced NAD $(0.25 \mathrm{mg}$. in $0.1 \mathrm{ml}$. phosphate buffer) was added, and the resultant mixture was allowed to equilibrate at $25^{\circ} \mathrm{C}$. for 30 minutes. The substrate $(0.022 \mathrm{~N}$-sodium pyruvate or $0.1 \mathrm{M}$-sodium $\alpha$-oxobutyrate, both at $p \mathrm{H} 7.4$ in phosphate buffer) $(0.1 \mathrm{ml}$.) was then added and the extinction at $340 \mathrm{~m} \mu$ was measured at $25^{\circ} \mathrm{C}$. Activities are expressed as micromoles of $\mathrm{NADH}_{2}$ oxidized per minute (i.u.).

Aspartate aminotransferase activity was determined by the method of Karmen (1955) and alanine aminotransferase (AIT) by the method of Wróblewski and LaDue (1956) both at $25^{\circ} \mathrm{C}$.

Aldolase activity was determined on non-haemolysed 
sera that had only been frozen once. A Biochemica test combination $^{1}$, based upon the method of Beisenherz, Boltze, Bücher, Czok, Garbade, Meyer-Arendt, and Pfleiderer (1953), was used. Activity was determined spectrophotometrically at $37^{\circ} \mathrm{C}$. and results are expressed as micromoles $\mathrm{NADH}_{2}$ oxidized per minute (i.u.).

Creatine phosphokinase activity was determined by the colorimetric method of Dreyfus and Schapira (1961) and results are expressed as micromoles of creatine liberated from creatine phosphate per minute (i.u.).

Acrylamide gel electrophoresis The method of Raymond and Weintraub (1959) was used in conjunction with the vertical electrophoresis apparatus ${ }^{2}$ of Raymond (1962).

$0.09 \mathrm{M}$-Tris buffer of $p \mathrm{H} 9.2$ was prepared by dissolving 2-amino-2-(hydroxymethyl)-1,3-propanediol (10.8 g.), ethylenediamine-tetra-acetic acid ( $0.93 \mathrm{~g}$.), and boric acid $(0.43 \mathrm{~g}$.) in deionized water and adjusting the volume to 1 litre.

Dimethylaminopropionitrile (300 mg.) was added to $150 \mathrm{ml}$. of a $5 \% \mathrm{w} / \mathrm{v}$ solution of Cyanogum 41 (acrylamide containing $5 \%$ methylene-bis-acrylamide) ${ }^{3}$ in $0.09 \mathrm{M}$-tris buffer $(p \mathrm{H} 9 \cdot 2)$. Ammonium persulphate (300 mg.) dissolved in $2 \mathrm{ml}$. tris buffer was added and the resulting solution was transferred without delay to the electrophoresis apparatus where it was allowed to gel. After about 30 minutes, the apparatus was filled with tris buffer, and water at 0 to $5^{\circ} \mathrm{C}$. was circulated through the cooling plates.

Bovine albumin $(20 \mathrm{mg} . / \mathrm{ml}$.) and a trace of bromophenol blue were added to each enzyme solution to serve as markers, and 15-50 $\mu \mathrm{l}$. (so as to give approximately equal total activities) was transferred to each slot. A potential of 25 to $30 \mathrm{volts} / \mathrm{cm}$. was applied for two to three hours, after which the gel was removed from the apparatus and immersed in the staining solution. This consisted of the tetrazolium salt, MTT $(15 \mathrm{mg}$.$) , NAD$ $(12 \mathrm{mg}$.$) , and phenazine methosulphate (0.5 \mathrm{mg}$.) dissolved in a mixture of $0.5 \mathrm{M}$-sodium lactate $(25 \mathrm{ml}$.) and $0.09 \mathrm{M}$-tris buffer (75 ml.). After 30 to $40 \mathrm{~min}$. the gel was extracted with water to remove unreacted tetrazolium salt and fixed in $10 \% \mathrm{v} / \mathrm{v}$ acetic acid.

Preparation of muscle extracts The muscle specimens were frozen at $-18^{\circ} \mathrm{C}$. until required for use. Portions

${ }^{1}$ C. F. Boehringer und Soehne, GmbH, Mannheim, Germany.

${ }^{2}$ E. C. Apparatus Corporation, Philadelphia, Pa.

${ }^{3}$ American Cyanamid Co. were sent by refrigerated air freight from London to Philadelphia packed with dry ice in a thermos flas. Comparable results were obtained in both laboratories.

Specimens $(200 \mathrm{mg}$.) were washed free from blood wish $0.9 \% \mathrm{NaCl}$ and were then homogenized at $0^{\circ} \mathrm{C}$. with $0.067 \mathrm{M}-$ Sørensen phosphate buffer at $p \mathrm{H} 7.4(0.6 \mathrm{ml}$.) fn a Potter-Elvehjem homogenizer with a Teflon pestle. The extracts were centrifuged at $3,000 \mathrm{~g}$ at $4^{\circ} \mathrm{C}$. for $10 \mathrm{~ms}$. and the supernatant fractions were separated. Electiophoresis and enzyme assays were carried out on freskefy prepared extracts. For enzyme determination, samples were suitably diluted (usually tenfold) with phosphate buffer.

\section{RESULTS}

Table I shows the HBD and LD enzyme levels in the four extracts of muscle from the available relatives in family $\mathrm{A}$ and in the control muscles. In all thrie brothers the LD activities were lower than in any oæe of the control series, and in the two affected members the difference was marked, but the enzyme levels for the mother were apparently normal. However, the four members of the family, especially the affected boys, had muscle HBD/LD ratios that were vergy much higher than any of the control values.

Figure 3 illustrates the LD isoenzyme pattern obtained by acrylamide gel electrophoresis of the extracts of normal (white) muscle, dystroph muscle, and muscle of the mother, a presumptioge carrier. In both affected children most activity wass observed in the fastest bands $\mathrm{LD}_{1}, \mathrm{LD}_{2}$, and $\mathrm{LD}_{3}$, whereas $\mathrm{LD}_{4}$ was faint and $\mathrm{LD}_{5}$ was not detectable. The patterns for the mother and the unaffected brother revealed larger proportions of the slow bands but in both cases $\mathrm{LD}_{1}, \mathrm{LD}_{2}$, and $\mathrm{LD}_{3}$ predominated, while in normal muscle $\mathrm{LD}_{3}, \mathrm{LD}_{4}$, and $\mathrm{LD}_{5}$ were the principal components.

Figure 4 shows the effect of replacing lactate $\alpha$-hydroxybutyrate, a substrate but little affected the slow moving isoenzymes characteristic of normal (white) muscle. It gives a clear demonstration of tbe qualitative difference between the lactate dehydrôgenases of normal and dystrophic muscle.

There appears to be an inverse relationsh

TABLE I

ENZYME ACTIVITIES IN MUSCLE FROM MEMBERS OF FAMILY A AND NORMAL SUBJECTS

\begin{tabular}{|c|c|c|c|c|c|c|}
\hline $\begin{array}{l}\text { Family A } \\
\text { Pedigree No. }\end{array}$ & Specimen & Muscle & Source & $\begin{array}{l}H B D \\
\text { (i.u./mg. protein) }\end{array}$ & $\begin{array}{l}L D \\
\text { (i.u./mg. protein) }\end{array}$ & $H B D / L D$ \\
\hline $\begin{array}{l}\mathrm{III}_{2} \\
\mathrm{III}_{3} \\
\mathrm{III}_{4} \\
\mathrm{II}_{8}\end{array}$ & $\begin{array}{l}\text { Dystrophic } \\
\text { Dystrophic } \\
\text { Normal } \\
\text { Normal } \\
\text { Control } \\
\text { Control } \\
\text { Control }\end{array}$ & $\begin{array}{l}\text { Triceps } \\
\text { Triceps } \\
\text { Triceps } \\
\text { Triceps } \\
\text { Triceps } \\
\text { Triceps } \\
\text { Latissimus dorsi } \\
\text { (7 specimens) }\end{array}$ & $\begin{array}{l}\text { Biopsy } \\
\text { Biopsy } \\
\text { Biopsy } \\
\text { Biopsy } \\
\text { Necropsy } \\
\text { Necropsy } \\
\text { Biopsy }\end{array}$ & $\begin{array}{ll} & 0.56 \\
& 0.38 \\
0.55 \\
1.39 \\
0.69 \\
0.49 \\
\text { Mean } & 1.29 \\
\text { S.D. } & 0.54 \\
\text { Range } & 0.84-2 \cdot 14\end{array}$ & $\begin{array}{ll} & 0.74 \\
& 0.48 \\
1 \cdot 00 \\
2 \cdot 01 \\
1 \cdot 87 \\
1 \cdot 19 \\
\text { Mean } & 4 \cdot 19 \\
\text { S.D. } & 1 \cdot 81 \\
\text { Range } 2 \cdot 18-7.58\end{array}$ & $\begin{array}{c}0.77 \\
0.81 \\
0.55 \\
0.69 \\
0.38 \\
0.41 \\
\text { Mean } 0.31 \\
\text { Range } 0 \cdot 28-0.35\end{array}$ \\
\hline
\end{tabular}




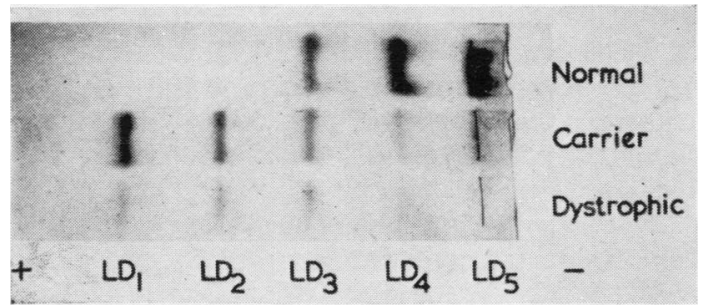

FIG. 3. Acrylamide gel electrophoresis of $L D$ isoenzymes of extracts of normal muscle, dystrophic muscle $\left(\mathrm{III}_{2}\right)$, and muscle from the mother of family $A\left(I I_{8}\right)$.

\subsection{3 (1) $\begin{aligned} & \text { Normal } \\ & \text { Dystrophic }\end{aligned}$}

FIG. 4. Acrylamide gel electrophoresis of LD isoenzymes of extracts of normal and dystrophic muscle treated with $\alpha$-hydroxybutyrate in place of lactate.

between the activities in muscle and sera; whereas the activities in muscle specimens from the dystrophic patients are much lower than those of the controls, the values for the corresponding sera were appreciably greater than the control figures.

Table II shows the serum levels of LD, HBD, AspT, AlT, aldolase, and creatine phosphokinase of the available members in both families. There was a high overall incidence of abnormal levels of dehydrogenase activity, the highest occurring in the dys- trophic boys, who also showed grossly elevated levels of AspT, aldolase, and creatine phosphokinase as compared with normal adults. In the serum of children over the age of a few weeks, the AspT, LD, and HBD activities were similar to those of adult serum. (We are indebted to Dr. S. B. Rosalki for the information that in his experience creatine phosphokinase levels are raised in infancy but fall to normal adult values by the fifth year of life. Aldolase activities, however, may be $50-100 \%$ higher in children up to the age of 10 .)

In family $\mathrm{A}$, the mother $\left(\mathrm{II}_{8}\right)$ and maternal grandmother $\left(\mathrm{I}_{2}\right)$ had high levels of SLD, SHBD, and aldolase. The maternal grandfather's serum had raised levels of SHBD and SLD but the normal transaminase, aldolase, and creatine phosphokinase values suggest a pathological condition other than muscle disease. The father $\left(\mathrm{II}_{1}\right)$ of the affected boys showed all enzyme levels within the normal range apart from a markedly high value for creatine phosphokinase. The sera for his two unaffected sons (III, $\mathrm{III}_{4}$ ) gave values within the normal range, but the four unaffected daughters (III $_{5}, \mathrm{III}_{6}, \mathrm{III}_{7}$, and $\mathrm{III}_{8}$ ) showed increased levels of SHBD and AspT, while $\mathrm{III}_{6}$ and $\mathrm{III}_{7}$ also showed a rise in the SLD and CPK levels, and $\mathrm{III}_{8}$ an associated increase in the SLD and aldolase activity. However, since $\mathrm{III}_{8}$ is only 4 years old, her aldolase level is not necessarily abnormal.

With the exception of aldolase all the enzyme levels of the affected boy ( $\mathrm{III}_{6}$ ) in family B were grossly elevated. An increase in the SHBD and creatine phosphokinase levels was shown by the 'carrier'

TABLE I I

SERUM ENZYME ACTIVITIES IN MEMBERS OF FAMILIES A AND B

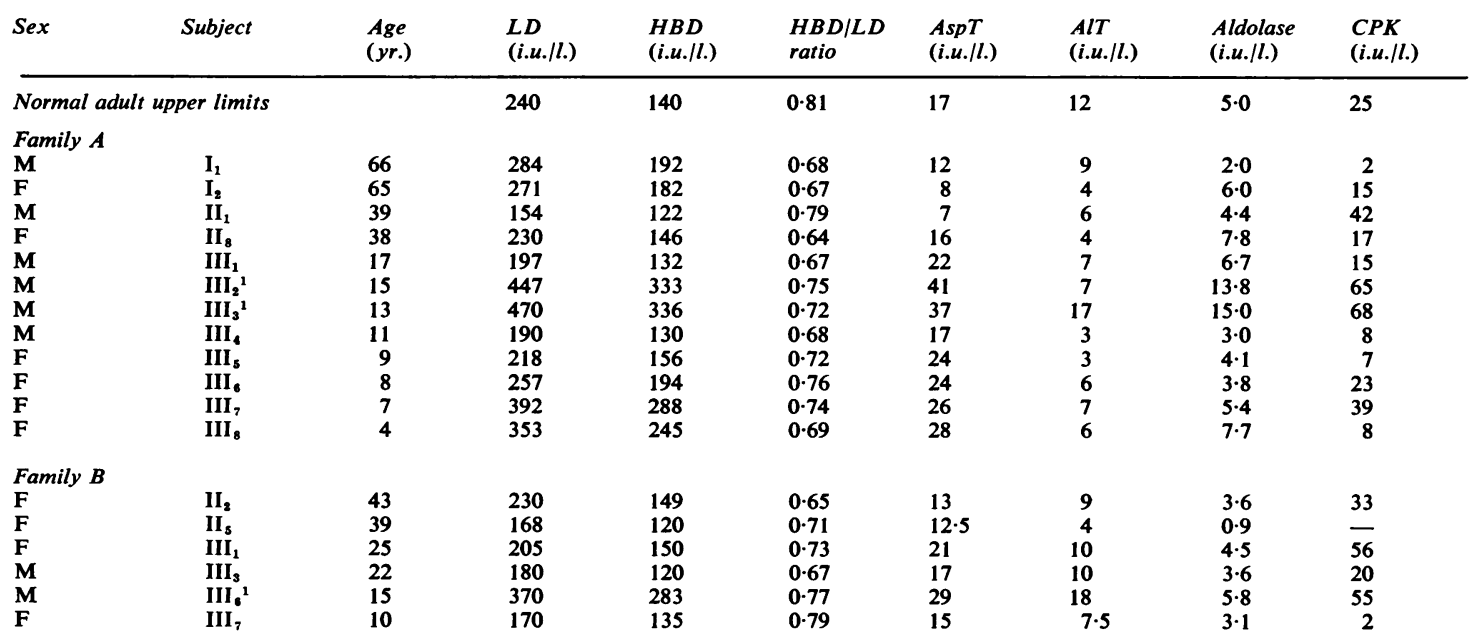


mother $\left(\mathrm{II}_{2}\right)$ and the unaffected half sister $\left(\mathrm{III}_{1}\right)$ who also had a raised AspT level; the unaffected full sister $\left(\mathrm{III}_{7}\right)$ had normal values. The unaffected brother $\left(\mathrm{III}_{3}\right)$ and the mother's sister $\left(\mathrm{II}_{5}\right)$ showed no increase in any of the serum enzyme levels.

In neither family did the HBD/LD ratio for the serum distinguish between the affected males, their unaffected relatives, and normal controls.

\section{DISCUSSION}

In these familial studies, the degree of LD and HBD enzyme activity found in the muscle of the different members cannot be reconciled with a simple sex-linked mode of inheritance, ncr do the results for sera reflect the enzyme activity in muscle.

The LD activity of the extracts from the dystrophic muscle, expressed per milligram of soluble protein, were only 6 to $62 \%$ of the corresponding values for the controls. It was also marginally lowered in the extract from the unaffected male sib, but appeared to be normal in the maternal specimen. In all four muscle extracts, however, the HBD/LD ratios were markedly greater than those for the controls, and the highest values were obtained with the dystrophic muscles. The ratios for the mother and unaffected male sib were intermediate between those for the affected sibs and the controls. These findings suggest the presence of a biochemical abnormality in the muscle of the unaffected individuals in whom no clinical signs of the disease can be found. An increase in the HBD/LD ratio has been shown to indicate a preponderance of the fast migrating isoenzymes $L D_{1}$ and $\mathrm{LD}_{2}$ (Rosalki and Wilkinson, 1960; Plummer et al., 1963), and we have been able to demonstrate by electrophoresis increases in those isoenzymes relative to normal muscle. This confirms the earlier electrophoretic studies of dystrophic muscle (Richterich et al., 1961; Wieme and Herpol, 1962; Dreyfus et al., 1962).

In the present work, the increased HBD/LD ratio in muscle clearly identifies the affected boys and the 'carrier female', but such interpretations are made with caution in view of the abnormal value shown by the unaffected male sib. The result in the unaffected boy was confirmed by independent determinations in London and in Philadelphia, but at present we cannot offer an explanation. A difference in the HBD/LD ratios of the order observed, however, is unlikely to be due to errors arising during enzyme determination, since the precision of the latter is within $\pm 5 \%$.

Determination of muscle enzyme activities in dystrophic muscle has recently been criticized because proliferation of connective tissue might lead to errors. In this work the muscle extracts were centrifuged to remove insoluble matter and the enzyme activities related to the soluble protein content. The results would be invalid only in the unlikely event of a compensating increase in the soluts protein content of muscle.

Several workers (Schapira et al., 1953; Dreyfus $\frac{\bar{Q}}{\mathrm{~g}}$ al., 1958; Vignos and Lefkowitz, 1959; Penningtớ, 1962) have reported that dystrophic muscle has lower activities of the glycolytic enzymes, aldolase and phosphorylase, and of creatine phosphokinase and adenylate kinase than normal muscle. Our fineing of reduced LD activity is consistent with that $\overrightarrow{\theta f}$ Heyck, Laudahn, and Lüders (1963) but confliets

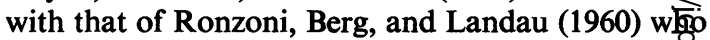
found the LD level to be increased though the aldolase and creatine phosphokinase levels were duced. This difference may in part be due to the duriar tion of the illness and the gross wasting of the musculature in both patients whom we studied. However, the low figures found in their asymptomatic brother and mother cannot be attributed to such cause.

A decrease in the $\mathrm{LD}_{5}$ content of muscle has been reported after experimental nerve section (Wierge and Lauryssens, 1962; Dawson et al., 1964; Lauryssens, Lauryssens, and Zondag, 1964) and Brody (1965) has recently shown that in guinea-pig resd muscle there is loss of $L D_{1}$. It may therefore be that changes in the LD isoenzyme content in human progressive muscular dystrophy are not specific for the dystrophic process, but are the consequence $\overrightarrow{\&} f$ changes in membrane permeability resulting in the disproportionate loss of the slow isoenzymes.

Whatever may be the mechanism involved, the is no doubt that the LD of dystrophic muscle, shown during this investigation, is different from that of comparable normal white muscle. Since $\mathbf{L} \mathbf{B}_{1}$ and $L_{2}$ are sensitive to inhibition by excess pyruvate, they are not capable of sustaining pio longed anaerobic glycolysis (Plagemann, Gregoty, and Wróblewski, 1960; Cahn, Kaplan, Levine, and Zwilling, 1962). Such isoenzymes occur in hed muscle which functions in an aerobic environmet, while normal white muscle isoenzymes $\mathrm{LD}_{4}$ and $\mathrm{LS}_{5}$ can continue to convert pyruvate into lactate in the presence of excess substrate. The predominance of $\mathrm{LD}_{1}$ and $\mathrm{LD}_{2}$ in dystrophic muscle may par $\mathrm{EPy}^{2}$ explain the three-fold decline in glycolytic activityas compared with normal muscle (Dreyfus et al., 1958).

In both families the serum enzyme levels for dystrophic boys were grossly elevated, but of equal importance were the elevated levels in the unaffectid females, all of whom are genetically 'at risk' $\mathrm{c}^{2 \mathrm{~s}}$ carriers of the harmful trait. The enzyme activities of the unaffected male sibs of the propositi in both families were within the normal range. 
The serum aldolase has not proved to be very satisfactory for detection of the carrier state (Leyburn, Thomson, and Walton, 1961; Clayton, Wilson, and Carter, 1963) and determination of creatine phosphokinase has been recommended as the most helpful biochemical test for this purpose (Aebi, Richterich, Colombo, and Rossi, 1961; Hughes, 1962; Wilson, Evans, and Carter, 1965). Of the potential female carriers in family $\mathbf{A}, \mathrm{III}_{6}$ and $\mathrm{III}_{7}$ exhibited abnormally raised serum creatine phosphokinase levels which were accompanied by high LD and HBD activities, thus giving an ominous prognosis for these two girls. Conversely, since $\mathrm{III}_{5}$ showed normal serum creatine phosphokinase and LD activities and her HBD level was only marginally elevated, this girl is not likely to carry the harmful gene.

The youngest girl, $\mathrm{III}_{8}$, had normal creatine phosphokinase activity but, in marked contrast, high LD and HBD levels. It is thus impossible to discriminate for or against the carrier state in this girl: her serum aldolase level, which is very similar to that of her mother, may not be abnormal in a child of 4 years. The question would probably be resolved by repetition of the enzyme studies when the child is older.

An interesting finding in family $\mathbf{A}$ is the high creatine phosphokinase activity observed on several occasions in the serum of the father $\left(\mathrm{II}_{1}\right)$, which has no apparent clinical explanation. As he was unemployed at the time, his raised levels cannot be attributed to strenuous muscular work. Such values are more likely to be found in a heterozygote carrier of the trait, but there is no evidence for any mode of inheritance other than sex-linked.

In family B, with known sex-linked inheritance, all the serum enzymes of the affected boy have high levels of activity. The increased serum HBD, AspT, and creatine phosphokinase activities shown by the eldest half-sister $\left(\mathrm{III}_{1}\right)$ is again a grave prognosis for the 'carrier state', but the youngest sister $\left(\mathrm{III}_{7}\right)$, in whom normal serum enzyme activities were observed, is not likely to be a carrier of the harmful gene. There is a very marked difference between the high serum HBD and creatine phosphokinase level for the carrier mother $\left(\mathrm{II}_{2}\right)$ and the normal level of her sister $\left(\mathrm{II}_{5}\right)$ who has an unaffected son.

In neither family was there an increase in the SHBD/SLD ratio above the upper normal limit $(0 \cdot 81)$, nor was there any significant difference between these ratios in the affected, the unaffected, and the control series. This is contrary to previous findings of high ratios (Elliott and Wilkinson, 1963); the difference may be due to the greater degree of genetic and clinical homogeneity of the present data.

Although the serum LD and HBD activities are not specific for identifying carrier females they do provide a useful adjunct to the evidence provided by the serum creatine phosphokinase level in these women. Schapira and Démos (1962) have reported a slight but significant increase in the maternal serum LD levels of 27 patients with dystrophy; the present work suggests that measurement of the serum HBD activity would give a more pronounced increase that might possibly be of greater diagnostic value than the LD determination. No single biochemical test has a high degree of accuracy when used for this purpose and it would appear that all the relevant enzyme assays are required to assess the potential carrier genotype of those girls in families with sexlinked muscular dystrophy.

We are indebted to Professor P. R. Allison, Nuffield Professor of Surgery, Radcliffe Infirmary, Oxford, for providing the control muscle and sera; Dr. H. Ellis, Churchill Hospital, Oxford, and Dr. E. Addenbrooke, Gloucester Royal Hospital, for referring the families; Dr. J. Thorne, Neurological Department, Radcliffe Infirmary, for his assistance in taking the muscle biopsies from members of family A; Dr. C. W. Hyde for some of the creatine phosphokinase determinations, and to the E-C Apparatus Corporation, Philadelphia, Pennsylvania, for providing the vertical electrophoresis apparatus. Technical assistance by Miss Margaret CromwellThomas, kindly financed by C. F. Boehringer und Soehne, G.m.b.H., Mannheim, Germany, and a grant for scientific assistance (to J.H.W.) by the Medical Research Council are gratefully acknowledged. One of us (J.H.W.) wishes to thank Dr. Robert F. Norris and the University of Pennsylvania for facilities to carry out some of the work during a visit to Philadelphia. This work was supported in part by U.S. Public Health Service Grant No. GM-10876 to Dr. Samuel Raymond, Pepper Laboratory of Clinical Medicine, Hospital of the University of Pennsylvania.

\section{REFERENCES}

Aebi, U., Richterich, R., Colombo, J. P., and Rossi, E. (1961). Enzymologia, 1, 61.

Beisenherz, C., Boltze, H. J., Bücher, T., Czok, R., Garbade, K. H., Meyer-Arendt, E., and Pfleiderer, G. (1953). Z. Naturforsch. $83,555$.

Brody, I. A. (1964). Neurology (Minneap.), 14, 1091

- (1965). Nature (Lond.), 205, 196.

Cahn, R. D., Kaplan, N. O., Levine, L., and Zwilling, E. (1962) Science, 136, 962.

Clayton, B. E., Wilson, K. M., and Carter, C. O. (1963). Arch. Dis. Childh., 38, 208.

Dawson, D. M., Goodfriend, T. L., and Kaplan, N. O. (1964). Science, 143, 929.

Dreyfus, J. C., Démos, J., Schapira, F., and Schapira, G. (1962). C. R. Acad. Sci. (Paris), 254, 4384.

, and Schapira, G. (1961). Rev. franc. Etud. clin. biol., 6, 700.

_, Schapira, G., and Démos, J. (1960). Ibid., 5, 384.

- - - and Schapira, F. (1958). Ann. N.Y. Acad. Sci., 75, 235.

Ebashi, S., Toyokura, Y., Momoi, H., and Sugita, H. (1959). J. Biochem. (Tokyo), 46, 103.

Elliott, B. A., and Wilkinson, J. H. (1961). Lancet, 1, 698.

- , and - (1963). Clin. Sci., 24, 343.

Heyck, H., Laudahn, C., and Lüders, C. J. (1963). Klin. Wschr., 41, 500 . 
Hughes, B. P. (1962). Brit. med. J., 2, 963.

- (1963). Proc. roy. Soc. Med., 56, 179.

Karmen, A. (1955). J. clin. Invest., 34, 131.

Konttinen, A. (1961). Lancet, 2, 556.

Lauryssens, M. G., Lauryssens, M. J., and Zondag, H. A. (1964). Clin. chim. Acta. 9, 276.

Leyburn, P., Thomson, W. H. S., and Walton, J. N. (1961). Ann. hum. Genet., 25, 41.

Pagliaro, L., and Notarbartolo, A. (1961). Lancet, 2, 1261.

Pearson, C. M. (1957). New Engl. J. Med., 256, 1069.

Pennington, R. J. (1962). Proc. Ass. clin. Biochem., 2, 17.

Plagemann, P. G. W., Gregory, K. F., and Wróblewski, F. (1960), J. biol. Chem., 235, 2288.

Plummer, D. T., Elliott, B. A., Cooke, K. B., and Wilkinson, J. H. (1963). Biochem. J., 87, 416.

Raymond, S. (1962). Clin. Chem., 8, 455.

$\longrightarrow$, and Weintraub, L. (1959). Science, 130, 711.

Richterich, R., Gautier, E., Egli, W., Zuppinger, K., and Rossi, E. (1961). Klin. Wschr., 39, 346.

Ronzoni, E., Berg, L., and Landau, W. (1960). Res. Publ. Ass. nerv. ment. Dis., 38, 721.
Rosalki, S. B. (1963). Brit. Heart. J., 25, 795.

- (1964). Personal communication.

- , and Wilkinson, J. H. (1960). Nature (Lond.), 188, 1110.

Schapira, F., and Démos, J. (1962). Enzymologia, 2, 45.

Schapira, G., Dreyfus, J. C., and Schapira, F. (1953). Sem. $H$ Paris, 29, 1917.

Sibley, J. A., and Lehninger, A. L. (1949). J. biol. Chem., 177, 859.

Thompson, R. A., and Vignos, P. J., Jr. (1959). Arch. intern. Me 103, 551 .

Thomson, W. H. S., Leyburn, P., and Walton, J. N. (1960). Bri med. J., 2, 1276.

Vignos, P. J., Jr., and Lefkowitz, M. A. (1959). J. clin. Invest., 38 873.

Wieme, R. J., and Herpol, J. E. (1962). Nature (Lond.), 194, 287. $\vec{\circ}$ - , and Lauryssens, M. J. (1962). Lancet, 1, 433.

Wilson, K. M., Evans, K. A., and Carter, C. O. (1965). Brit. med. 1,750 .

Wróblewski, F., and LaDue, J. S. (1955). Proc. Soc. exp. Biol. (N. 요 90, 210. (1956). Ann. intern. Med., 45, 801. 